\title{
PENGARUH PRODUK BANK MUAMALAT TERHADAP PERTUMBUHAN USAHA MIKRO KECIL MENENGAH DI KOTA PALOPO
}

\author{
Mukhtaram Ayyubi \\ Fakultas Syariah Institut Agama Islam Negeri (IAIN) Palopo \\ Email : ay2ubi@gmail.com
}

\begin{abstract}
This research aims to know and analysis the business capital, investment and consumptive toward small micro and medium growing in Muamalat Syariah Bank Branch of Palopo, and to know and analysis between the product have dominant impact toward small, micro and medium enterprise growing in Muamalat Syariah Bank Branch of Palopo. The result of research to found that the product of Muamalat Syariah Bank such as business capital, investment and consumptive in simultaneous affected in positive and significant toward small, micro and medium enterprise growing at Palopo. And in partial the product have applied to customer as attempt to increase of small, micro and medium growing at Palopo City. Based on the result to found that the business capital have dominant affected positive and significant toward UMKM growing at Palopo. This mean the capital to give from client or customer suitable with appointment which to insurance it, would support increasing the UMKM growing.
\end{abstract}

Keywords: Capital of bussines, Investment, small micro and medium enterprise.

\begin{abstract}
Abstrak
Penelitian ini bertujuan untuk mengetahui dan menganalisis modal usaha, investasi dan konsumtif terhadap pertumbuhan mikro kecil dan menengah di Bank Muamalat Syariah Cabang Palopo, serta untuk mengetahui dan menganalisis antara produk yang memiliki pengaruh dominan terhadap usaha kecil, mikro dan menengah yang tumbuh di Muamalat Syariah Cabang Bank Palopo. Hasil penelitian menemukan bahwa produk Bank Muamalat Syariah seperti modal usaha, investasi dan konsumtif secara simultan berpengaruh positif dan signifikan terhadap pertumbuhan usaha kecil, mikro dan menengah di Palopo. Dan secara parsial produk telah diterapkan pada pelanggan sebagai upaya untuk meningkatkan pertumbuhan kecil, mikro dan menengah di Kota Palopo. Berdasarkan hasil penelitian diketahui bahwa modal usaha dominan berpengaruh positif dan signifikan terhadap pertumbuhan UMKM di Palopo. Ini berarti modal untuk diberikan dari klien atau pelanggan yang sesuai dengan perjanjian yang akan mengasuransikannya, akan mendukung peningkatan pertumbuhan UMKM.
\end{abstract}

Kata Kunci : Modal Bisnis, Investasi, Perusahaan Kecil dan Menengah 


\section{PENDAHULUAN}

Perbankan syari'ah dikenal dengan istilah Islamic Banking atau disebut interestfree banking. Bank syariah pada awalnya dikembangkan sebagai sebuah respon dari kelompok ekonom dan praktisi perbankan muslim yang berupaya mengakomodasi desakan dari berbagai pihak yang meng-inginkan agar tersedia jasa transaksi keu-angan dilaksanakan sejalan dengan nilai moral dan prinsip syariah Islam. Utamanya berkaitan dengan pelarangan praktik riba dan kegiatan maisir (spekulasi) dan gharar (ketidakjelasan).

Bank Syariah merupakan lembaga keuangan yang usaha pokoknya memberikan pembiayaan dan jasa lainnya dalam lalu lintas pembayaran serta peredaran uang yang pengoperasiannya sesuai dengan prinsip syariah Islam. Bank Syariah ini merupakan bank yang beroperasi sesuai prinsip syariah Islam, bank yang tata cara operasionalnya disesuaikan dengan ketentuan Islam, khusus-nya yang menyangkut tata cara bermuamalah secara Islam. Tata cara tersebut jauh dari praktek yang dikhawatirkan mengandung unsur riba untuk diisi dengan peran aktivitas bank syariah dalam hal pengelolaan modal kerja, investasi dan konsumtif atas dasar bagi hasil untuk meningkatkan pertumbuhan UMKM.

Bank secara umum adalah lembaga perantara keuangan atau biasa disebut financial intermediary artinya lembaga bank yang beraktivitas dalam menangani masalah modal, investasi dan biaya konsumtif. Karena itu masalah perbankan selalu men-jadikan hal itu sebagai alat pelancar ter-jadinya perdagangan. Kegiatan dan usaha bank selalu berkaitan dengan komunitas antara lain: 1) memindahkan aset; 2) menerima dan membayar kembali aset dalam rekening koran; 3) mendiskonto surat wesel, surat order maupun surat berharga lainya; 4) membeli dan menjual surat berharga; 5) membeli dan menjual cek surat wesel kertas dagang; dan 6) memberikan jaminan perbankan.

Menghindari pengoperasian bank dengan sistem bunga, Islam memperkenal-kan prinsip muamalah Islam. Bank Syariah lahir sebagai salah satu solusi alternatif terhadap pertentangan antara bunga bank dengan riba. Inilah yang menjadikan Undang- 
Undang Perbankan direvisi dari UU Nomor 7 Tahun 1992 menjadi UU Perbankan Nomor 10 Tahun 1998, dalam bentuk sebuah bank yang pengoperasiannya dengan sistem bagi hasil atau bank syariah. Kaitan antara bank dengan modal kerja, investasi dan biaya dalam satu unit bisnis adalah penting, namun dalam pelak sanaannya harus menghilangkan ketidak-adilan, ketidakjujuran dan penghisapan dari satu pihak ke pihak lain (bank dengan nasabahnya).

Kedudukan bank Islam dalam hubungan kepada klien adalah sebagai mitra investor dan pedagang, sedangkan dalam bank umumnya hubungannya sebagai kreditor dan debitur. Jalinan investor dengan nasabah dalam menjalankan pekerjaannya, bank syariah menggunakan berbagai teknik dan metode kontrak mudharabah. Mekanisme perbankan syaraiah dengan sistem ini yaitu menerapkan prinsip mitra usaha yang bebas bunga, karena itu peranan bank syariah menjadi momentum penting dalam mewujudkan kemaslahatan umat dalam melakukan aktivitas muamalah.

Karakteristik sistem perbankan syari-ah yang beroperasi berdasarkan prinsip bagi hasil memberikan alternatif sistem per-bankan yang saling menguntungkan bagi masyarakat dan bank, serta menonjolkan aspek keadilan dalam bertransaksi, investasi yang beretika, mengedepankan nilai-nilai kebersamaan dan persaudaraan dalam berperan, dan menghindari kegiatan spekulatif dalam bertransaksi keuangan. Dengan menyediakan beragam produk serta layanan jasa perbankan yang beragam dengan skema keuangan yang lebih bervariatif, perbankan syariah menjadi alternatif sistem perbankan yang kredibel dan dapat dinikmati oleh seluruh golongan masyarakat tanpa ter-kecuali.

Konsep permodalan yang diberikan oleh Bank Muamalat Syariah dalam mengembangkan perannya ini mengacu pada teori perputaran modal yang dikemukakan oleh Wirtz (2007:24) bahwa perputaran modal akan menghasilkan saham, keuntungan, cadangan umum dan laba dari setiap usaha. Wujud usaha menurut teori ini dalam prakteknya berupa modal kerja primer, normal, musiman, siklis dan darurat. Teori ini yang kemudian menjadi dasar Bank Muamalat Syariah memainkan 
peranannya untuk mengelola modal pihak ketiga secara mudarabah sesuai konsep bagi hasil yang saling menguntungkan.

Produk mudharabah lain yang dijalan-kan oeh Bank Muamalat Syariah Cabang Palopo dalam mengelola aktivitasnya yaitu memenuhi kebutuhan masyarakat melalui investasi yaitu memberikan peluang dan keuntungan kepada nasabah melalui investtasi yang ditanamkan. Wujud peran perban-kan dalam pemberian investasi berupa depo-sito, pasar modal, obligasi dan reksadana. Bentuk investasi ini dijalankan berdasarkan hasil bagi sesuai dengan ketentuan yang berlaku.

Dasar teori yang dikemukakan yaitu teori investasi dikemukakan oleh Murdock (2007:35) bahwa investasi merupakan cadangan pertumbuhan modal yang tersimpan berjalan sesuai dengan tempo waktu penggu-naannya. Wujud dari bentuk investasi yang diterapkan oleh bank syariah berupa akti-vitas deposito, pasar modal, obligasi dan reksadana.

Bank Syariah Cabang Palopo juga menawarkan produk dalam pembiayaan konsumtif. Pembiayaan konsumtif yang dimaksud adalah pembiayaan konsumsi rumah tangga dan non rumah tangga yang diberikan kepada nasabah untuk digunakan sesuai dengan tingkat kebutuhan konsumsi yang dilakukan. Wujud dari biaya konsumtif yang diterapkan berupa pemberian kredit pemilikan rumah (KPR), kredit pemilik mobil (KPM), tunjangan pendidikan dan kesehatan.

Teori yang mendasari yaitu teori surveillance yang dikemukakan oleh Allince (2007:39) bahwa setiap kelangsungan hidup bergantung pada konsumsi setiap orang yang harus mendapatkan pembiayaan. Meringan-kan pembiayaan berarti mendukung kelang-sungan hidup. Ini berarti pembiayaan kon-sumtif merupakan tujuan dari pihak per-bankan untuk memberikan kelangsungan hidup dari nasabahnya melalui pemberian biaya konsumtif. Wujud biaya konsumtif yang diterapkan berupa KPR, KPM, pem-berian tunjangan pendidikan dan kesehatan.

Berdasarkan ketiga produk Bank Syariah dalam mewujudkan sistem kerja perbankan yang mempunyai prinsip mudha-rabah melalui peranan modal kerja, investasi dan konsumtif diharapkan meningkatkan pertumbuhan UMKM. Bagi bangsa 
Indo-nesia, pertumbuhan UMKM yang diterapkan saat ini meliputi pengelolaan ekonomi ber-skala kecil, menengah dan besar, tergantung pada jenis usaha, modal usaha dan penye hatan pengelolaan usaha yang dimiliki nasabah.

Pertumbuhan UMKM yang ada di Indonesia saat ini menunjukkan fenomena yang tidak berjalan secara optimal. Alasan-nya bahwa nasabah dalam hal ini pengusaha (baik berskala kecil, menengah dan besar), mempunyai keterbatasan dalam mendapatkan modal kerja, investasi dan biaya konsumtif, yang menyulitkan untuk mem-perluas dan memperbesar pengembangan usaha. Karena itu, pihak pengusaha senan-tiasa membutuhkan peranan bank syariah untuk membantu dalam menghidupkan usahanya.

Teori yang mendukung yaitu teori penguatan ekonomi yang dikemukakan oleh Jhingan (2008:19) bahwa pertumbuhan ekonomi menjadi kuat bila andil bank mampu memainkan peranan dalam member-dayakan usaha masyarakat. Ini relevansi pula dengan konsep entrepreneurship yang dikemukakan oleh Mussry (2007:135) bah-wa aset modal kerja, investasi dan konsumtif merupakan sumber penciptaan kewirausahaan dalam melakukan pemberdayaan ekonomi lokal. Sampai saat ini mitra usaha dalam berpartisipasi pada kegiatan penge-lolan ekonomi lokal masih kurang, karena terbatasnya bantuan pihak bank syariah dalam memainkan perannya untuk meningkatkan pengelolaan ekonomi masyarakat sebagai basis penguatan ekonomi lokal. Pihak bank syariah dalam menjalin ke-mitraan dengan nasabah khususnya peng-usaha, belum mampu memainkan peranan-nya dengan baik. Kecenderungan pemberian hanya diperuntukkan bagi mitra usaha yang telah memiliki usaha sebelumnya dan mitra yang mempunyai jaminan usaha. Pertim-bangan lain bahwa bagi hasil keuntungan yang diperoleh dari aktivitas kemitraan dengan prinsip syariah cenderung bersifat stagnan dibandingkan dengan pemberian keuntungan suku bunga yang diberikan Bank Konvensional.

Inilah yang menjadi problematika untuk melihat dan mengamati pengaruh produk mudharabah Bank Muamalat Syariah dalam pembangunan ekonomi lokal khusus-nya untuk mengikutsertakan nasabah atau pengusaha (berskala kecil, menengah dan besar) untuk mengambil andil dalam per-tumbuhan UMKM dengan menjadi mitra pihak bank 
dalam mendapatkan modal kerja, investasi dan biaya konsumtif untuk memi-liki usaha yang secara bertahap dan berke-sinambungan saling memberikan keun-tungan antara kedua pihak (bank dan nasabah) sebagai pemberi dana (fund provider) dan mitra usaha (partnership business). Berdasarkan fenomena ini maka penulis tertarik untuk membahasa tentang bagaimana produk mudharabah Bank Muamalat Syariah berupa pemberian modal kerja, investasi dan konsumtif berpengaruh terhadap partum-buhan UMKM di Kota Palopo dan produk mudharabah Bank Muamalat Syariah mana yang dominan berpengaruh terhadap pertumbuhan UMKM di Kota Palopo

Adapun deskripsi karakteristik responden merupakan penjelasan tentang keberadaan pengusaha UMKM sebagai nasabah Bank Muamalat Syariah Cabang Palopo, yang diperlukan sebagai informasi sesuai identitas sebagai responden dalam penelitian ini. Responden memberikan interpretasi untuk menganalisis pengaruh produk mudharabah Bank Muamalat Syariah terhadap pertumbuhan UMKM di Kota Palopo. Responden dalam penelitian ini sebanyak 121 orang yang representatif untuk dikemukakan sebagai kelayakan dalam memberikan informasi sesuai identitas diri mulai dari jenis kelamin, umur, pendidikan dan masa kerja.

\section{MODAL KERJA TERHADAP PERTUMBUHAN UMKM}

Usaha Mikro Kecil dan Menengah (UMKM) di Kota Palopo dapat berbentuk perusahaan perorangan, persekutuan mau-pun perserorang terbatas. UMKM dapat dikategorikan menjadi 3 terutama berdasar jumlah asset dan omzet sebagaimana tercantum pada Undang-Undang Nomor 70 Tahun 2008 tentang UMKM. Usaha menengah usaha ekonomi produktif berdiri sendiri dilakukan oleh orang perseorangan atau badan usaha yang bukan merupakan anak perusahaan atau cabang perusahaan yang dimiliki, dikuasai atau menjadi bagian baik langsung maupun tidak langsung dengan usaha kecil atau usaha besar.

Modal kerja berpengaruh positif dan signifikan terhadap pertumbuhan UMKM yang diterapkan oleh Bank Muamalat Syariah kepada pihak mitra usaha yang ada di 
Kota Palopo. Modal usaha yang diberikan oleh pihak perbankan berupa modal kerja primer, normal, musiman, siklis dan darurat dalam menjalankan berbagai usaha yang dikembang-kan pelaku mitra usaha untuk memajukan usahanya.

Penerapan modal kerja yang diberikan oleh pihak perbankan sangat membantu pelaku usaha di dalam meningkatkan per-tumbuhan UMKM. Ini dilihat dari penggunaan modal kerja primer yaitu modal ker-ja yang utama dalam menopang berbagai kegiatan pembelian produk barang dan jasa usaha yang dapat memajukan usaha yang dilakukan mitra dalam mendukung perkem-bangan dan kemajuan usaha. Melalui pemberian modal kerja primer ini, secara lang-sung dan tidak langsung membantu pihak mitra mengembangkan usahanya dan mem-pengaruhi pertumbuhan UMKM yang ada di Kota Palopo.

Pihak perbankan di dalam member-kan modal usaha kepada pihak mitra, menyesuaikan menurut permintaan atau usulan atas modal yang dapat dikembalikan dan dijaminkan dapat meminimumkan pengembalian modal (turnover capital). Salah satu modal usaha yang diberikan pihak perbankan berupa modal kerja normal yaitu pemberian modal atas usaha sesuai dengan standar normal yang ditetapkan, penentuan standar normal ini didasarkan pada kegiatan penjaminan yang dimiliki oleh pihak mitra sesuai aset dan kekayaan yang dimiliki yang dapat mengembalikan modal yang dipinjamkan. Biasanya pihak mitra menunjukkan aset dan bukti-bukti yang dapat dijaminkan untuk memberikan keya-kinan pihak perbankan dalam memberikan modal usaha normal. Pemberian modal kerja usaha normal ini sangat membantu pengembangan dan penganekaragaman usaha pihak mitra untuk meningkatkan pertumbuhan UMKM di Kota Palopo.

Mengembangkan berbagai kegiatan usaha yang dilakukan pihak mitra Kota Palopo, terkadang bergantung pada kondisi kelancaran atau karakteristik usaha yang ditekuni oleh pihak mitra. Kondisi usaha ini yang biasa disebut dengan usaha musiman yang mem-butuhkan modal kerja sesuai dengan kegiatan usaha yang dilakukan oleh pihak mitra. Memahami kondisi musiman dari usaha mitra, maka pihak perbankan telah mem-pertimbangkan waktu pemberian modal yang sesuai dengan kondisi yang 
memungkinkan perusahaan tersebut berkem-bang dan maju. Indikasi dalam memahami musiman biasanya dilihat dari periode tertentu terjadinya peningkatan produksi, tingkat permintaan tinggi, dan pengem-bangan usaha yang banyak membutuhkan produk dan jasa atas usaha yang dilakukan oleh pihak mitra, sehingga membutuhkan modal untuk menambah kapasitas, kegiatan dan omzet penjualan dengan memberikan rangsangan atau bantuan modal kerja sesuai kebutuhannya. Pemberian modal kerja musiman ini sangat membantu pihak mitra usaha melalui bantuan perbankan mengem-bangkan usahanya dalam meningkatkan pertumbuhan UMKM di Kota Palopo.

Bagi pengambil keputusan perbankan di dalam memberikan bantuan modal kerja kepada pihak mitra usaha, selalu mem-pertimbangkan jenis usaha yang ditekuni menurut siklis perputaran modal yang mampu dilakukan oleh pihak mitra usaha.

Pertimbangan bahwa perputaran mo-dal yang cepat dan mempunyai pertumbuhan yang selalu meningkat dalam setiap periode, menjadi pertimbangan bagi pihak perbankan untuk memberikan modal usaha siklis dalam rangka membantu lebih mempercepat per-putaran modal kerja., agar usaha yang ditekuni senantiasa mengalami peningkatan, sehingga memudahkan mampu mengembali-kan modal usaha yang diberikan. Modal kerja usaha siklis ini sangat dibutuhkan pihak mitra untuk menjaga pengembangan dan keberlanjutan usaha yang ditekuni untuk terus meningkatkan pertumbuhan UMKM di Kota Palopo.

Pemberian modal kerja yang diterap-kan oleh pihak perbankan, tidak hanya semata-mata berorientasi pada aspek eko-nomi, tetapi juga berorientasi pada aspek sosial yang peranannya mempengaruhi pertumbuhan UMKM. Atas dasar ini, maka dikeluarkan kebijakan pemberian modal usaha berupa modal kerja darurat yaitu pemberian modal dari pihak mitra tanpa mempertimbangkan aset ekonomi yang dimiliki oleh pihak mitra usaha, namun melihat aspek kondisional yang representatif mendukung aktivitas usaha bisa berkembang dan maju. Biasanya pemberian modal kerja darurat ini diberikan kepada mitra usaha pemula, atau mitra usaha yang menjadi binaan dari perbankan untuk memulai usaha yang dituntut mampu berkembang dan maju, sehingga pelaku usaha tidak dituntut secara periode melakukan pengembalian 
modal yang tepat waktu. Melalui pemberian modal kerja darurat ini sangat berperan dalam membantu mitra usaha untuk meningkatkan pertumbuhan UMKM di Kota Palopo.

Berdasarkan uraian yang dikemukakan di atas, dipahami bahwa modal usaha yang diberikan oleh pihak perbankan kepada pihak mitra menyeluruh dan parsial memberikan pengaruh positif dan signifikan ter-hadap pertumbuhan UMKM di Kota Palopo. Ini dapat dilihat dari meningkatnya pengem-bangan usaha yang dilakukan oleh pihak mitra baik berupa usaha mikro, kecil dan menengah, yang setiap waktu mengalami peningkatan jenis usaha dan penganeka-ragaman usaha yang ditekuni oleh masya-rakat sebagai pelaku usaha yang bermitra dengan pihak perbankan dalam hal ini seba-gai nasabah Bank Muamalat Syariah. Teori yang mendukung dikemukakan oleh Dhar-man (205:78) bahwa bagi pihak peru-sahaan, insentif modal kerja sangat berperan penting dalam memajukan perusahaan. Bagi perusahaan kecil dan menengah, modal kerja sangat penting untuk memberikan kelang-sungan hidup dalam pengoperasian dan produksi perusahaan. Jenis modal kerja baik berupa modal kerja primer, normal, musiman, siklis dan darurat berproduk penting dalam memperkuat eksistensi ekonomi perusahaan, khususnya dalam memajukan perusahaan sesuai dengan ting-kat pengelolaan usaha yang dapat dikem-bangkan. Untuk itu diperlukan manajemen modal kerja yang diyakini sangat ber-pengaruh terhadap tingkat profitabilitas suatu perusahaan.

\section{INVESTASI TERHADAP PERTUMBUHAN UMKM}

Berdasarkan hasil penelitian menun-jukkan bahwa investasi memberikan pengaruh positif dan signifikan terhadap per-tumbuhan UMKM. Kegiatan investasi yang dilakukan oleh perbankan pada dasarnya melakukan kegiatan capital good atau barang modal yang dapat dijadikan sebagai investasi. Kegiatan investasi memainkan peranan penting dalam perekonomian rakyat, termasuk dalam hal ini jenis investasi yang bersumber dari deposito, pasar modal, obligasi dan reksadana. Sumber investasi ini dikelola oleh pihak perbankan untuk dimanfaatkan dan digunakan sebagai dana 
investasi untuk dikelola oleh pihak mitra usaha dalam meningkatkan pertumbuhan UMKM termasuk yang ada di Kota Palopo.

Penerapan investasi yang bersumber dari pengelolaan pihak bank dari dana deposito nasabah, tentunya sangat mem-pengaruhi kemampuan pihak perbankan di dalam melakukan pengelolaan dana deposito untuk disalurkan kepada pihak mitra usaha. Semakin besar investasi yang bersumber dari deposito nasabah, semakin besar pengaruhnya terhadap perkembangan usaha mitra. Karena itu pihak bank senantiasa memberikan pengelolaan modal usaha sesuai dengan besarnya deposito yang dimiliki oleh pihak mitra usaha, sehingga pembiayaan usaha dapat dikelola melalui pengembalian yang bersumber dari deposito kepemilikan nasabah dan beberapa nasabah lain yang menginvestasikan untuk dikelola pendanaanya berdasarkan ketentuan periode yang telah ditetapkan.

Bagi pihak perbankan, termasuk dalam hal ini Bank Muamalat Syariah dalam mengelola dana masyarakat atau dana pihak ketiga juga memanfaatkan pengelolaan sumber daya dari aktivitas pasar modal yaitu melakukan kegiatan menjual dan membeli modal berdasarkan besarnya saham kepemi-likan yang kemudian diberikan kepada pihak mitra usaha untuk dapat dimanfaatkan dan digunakan dalam pengelolaan usaha yang dikembangkan. Penggunaan investasi mela-lui kegiatan pengelolaan yang bersumber dari kegiatan pasar modal, akan memberikan prospektif kegiatan perputaran dan peman-faatan investasi dapat berputar sesuai dengan kondisi pasar modal. Karena itu kondisi pasar modal yang sehat memberikan ke-untungan peningkatan investasi yang dapat dimanfaatkan untuk dikelola oleh pihak mitra dalam mengelola usahanya dan hal ini memberikan pengaruh pertumbuhan UMKM yang ada di Kota Palopo.

Mengembangkan aktivitas investasi yang dilakukan oleh pihak perbankan dalam mengelola sumber pendanaan pihak ketiga yang diberikan kepada pihak mitra untuk dimanfaatkan dan digunakan dalam mening-katkan perkembangan usahanya dapat diper-oleh dari sumber dana obligasi. Pendanaan dari investasi obligasi yang dikelola pihak perbankan yaitu penggunaan surat-surat berharga yang dapat dijaminkan sebagai aset atau kekayaan investasi yang dapat dicairkan untuk digunakan kepada pihak mitra 
dalam mengembangkan usahanya. Surat-surat ber-harga berupa obligasi yang dimiliki oleh nasabah dapat dimanfaakan oleh pihak per-bankan untuk diinvestasikan dan dicairkan menjadi pendanaan usaha yang dapat mem-bantu pihak mitra usaha untuk mengem-bangkan usahanya dan ini memberikan pengaruh pertumbuhan UMKM yang di-terapkan oleh Bank Muamalat Syariah yang ada di Kota Palopo.

Termasuk halnya pemanfaatan dan penggunaan surat berharga yang dimiliki oleh pihak nasabah berupa reksadana yang dapat diberikan kepada nasabah oleh pihak bank sebagai jaminan untuk mendapatkan dana investasi yang dikelola oleh pihak ke-tiga dalam hal ini nasabah mitra usaha untuk mengembangkan usahanya. Pemberian investasi yang bersumber dari surat berharga reksadana yang ditawarkan kepada pihak ketiga mampu membantu dan dimanfaatkan oleh pihak lainnya dalam mengelola usaha kmitraan yang dapat berkembang dan produktif. Karena itu pemberian investasi dari sumber reksadana membantu pihak mitra dalam mengembangkan usahanya untuk meningkatkan pertumbuhan UMKM yang dilakukan oleh pihak perbankan Bank Muamalat Syariah yang ada di Kota Palopo.

Berdasarkan uraian yang dikemuka-kan di atas, diketahui bahwa penerapan investasi yang dilakukan pihak perbankan dalam hal ini Bank Muamalat Syariah yang memanfaatkan sumber investasi dari pihak ketiga berupa deposito, pasar modal, obligasi dan reksadana berperan penting bagi pihak perbankan untuk dimanfaatkan dan dikelola oleh pihak ketiga dalam hal ini pihak mitra usaha atas investasi yang ditanamkan oleh nasabah kepada Bank Muamalat Syariah untuk dikelola secara proporsional sesuai dengan orientasi pen-danaan bisnis atau usaha yang menunjang pengembangan usaha mitra dalam mening-katkan pertumbuhan UMKM. Penerapan UMKM. Ini dapat dilihat dari pemfaatan investasi nasabah perbankan, kegiatan usaha mitra terus berkembang dan maju, baik dalam bentuk skala usaha mikro kecil dan menengah yang banyak di Kota Palopo.

Teori mendukung dikemukakan oleh Halim (2004:129) menyatakan bahwa kegia-tan investasi yang dilakukan oleh suatu per-bankan pada dasarnya melakukan kegiatan capital good atau barang modal yang dapat dijadikan sebagai investasi. 
Capital goods atau barang modal yang dapat diinvestasikan antara lain berupa tanah, gedung, bangunan, mesin dan peralatan, aset dan lain-lainnya yang dapat menghasilkan barang modal. Kegiatan investasi memainkan peran penting dalam perekonomian suatu bangsa, karena-nya diperlukan adanya ciri-ciri khusus mengenai suatu kegiatan investasi.

Termasuk teori total investasi (invest-ment total theory) yang dikemukakan oleh Dernard (2009) bahwa pertumbuhan usaha selalu berorientasi pada besarnya total investasi yang ditanamkan. Makin besar investasi yang dimanfaatkan, maka semakin besar beban pikul pengelolaan untuk dikem-bangkan dalam memperoleh keuntungan. Relevansi teori ini dengan kondisi investasi yang dimanfaatkan oleh pihak Bank dari sumber daya pihak ketiga baik berupa depo-sito, pasar modal, obligasi dan reksadana merupakan beban yang dipikul oleh pihak perbankan, karenanya perlu pengelolaan pertukaran dan penyaluran dana investasi tersebut untuk memperoleh keuntungan atas penggunaan investasi.

\section{KONSUMTIF TERHADAP PERTUMBUHAN}

Berdasarkan hasil penelitian menun-jukkan bahwa pengelolaan dana konsumtif yang dilakukan oleh pihak perbankan mem-berikan pengaruh positif dan signifikan terhadap pertumbuhan UMKM yang diberikan kepada pihak mitra usaha dalam mengembangkan usahanya. Dana konsumtif meru-pakan salah satu produk perbankan berupa pembiayaan yang diberikan kepada nasabah untuk digunakan sesuai dengan tingkat kebutuhan konsumsi yang dilakukan. Produk tersebut berupa KPR, KPM, pendidikan dan kesehatan dalam mendukung pengembangan potensi mitra usaha untuk meningkatkan pertumbuhan UMKM yang ada di Kota Palopo.

Bank Muamalat Syariah yang meru-pakan lembaga yang bergerak pada jasa keuangan syariah. Lembaga ini selain mengum-pulkan uang masyarakat juga memberikan kredit kepada masyarakat baik untuk kepen-tingan konsumtif maupun untuk kegiatan usaha. Salah satu wujud pemenuhan kebutu-han konsumtif bagi banyak nasabah atau mitra usaha untuk terpenuhi kebutuhannya adalah tuntutan kepemilikan rumah. Hal ini 
penting mengingat bahwa pihak mitra dalam mengelola usahanya membutuhkan tuntutan ketersediaan tempat tinggal yang biasanya juga dimanfaatkan untuk tempat berusaha. Melalui jasa bantuan perbankan untuk memenuhi kebutuhan konsumtif tersebut, pihak bank biasanya memberikan bantuan berupa kredit yang biasa disebut dengan Kredit Perumahan Rakyat (KPR). Melalui KPR ini pihak mitra dapat mengusulkan kepada pihak bank untuk dikreditkan rumah tempat tinggal/usaha sesuai dengan jaminan, kemampuan pembayaran, dan kegiatan usa-ha yang dimiliki pihak mitra. Melalui penya-luran KPR ini, sangat membantu pihak mitra mengembangkan usahanya dan memberikan jaminan terpenuhi kebutuhan konsumtif da-lam menekuni usaha dan hal ini berpengaruh terhadap pertumbuhan UMKM yang ada di Kota Palopo.

Pemberian produk mudharabah yang dikembangkan oleh pihak perbankan Bank Muamalat Syariah berupa pemberian Kredit Pemilikan Mobil (KPM). Kredit konsumtif KPM ini sangat membantu pihak mitra usaha untuk mengembangkan usahanya dan terpenuhi kebutuhan rumah tangga yaitu untuk memperlancar kegiatan usaha dan pemenuhan kebutuhan keluarga atas ke-pemilikan kendaraan yang dibayarkan oleh pihak bank baik berupa kendaraan roda empat untuk menunjang aktivitas usaha pihak mitra. Pelunasan kredit yang dilaku-kan oleh pihak mitra ke pihak perbankan sangat membantu dalam meringankan beban pembiayaan yang besar dan pengalokasian modal yang digunakan untuk membeli mobil. Atas pembayaran yang dilakukan oleh pihak bank membantu kelancaran usaha dan meringankan pembiayaan setiap bulan atas tanggungan biaya yang dikenakan. Bantuan biaya konsumtif ini memberikan pengaruh terhadap perkembangan usaha dan terpenuhinya kebutuhan konsumtif untuk dapat meningkatkan pertumbuhan UMKM yang ada di Kota Palopo.

Termasuk dalam hal ini produk mudharabah Bank Muamalat Syariah yang ditawarkan kepada mitra usaha adalah pemberian asuransi pendidikan yaitu untuk memberikan kemudahan dan jaminan ke-pada pihak mitra usaha agar dapat memanfaatkan dan menggunakan jasa asuransi pendidikan ini untuk membiayai pendidikan anggota keluarganya. Hal ini relevan dengan kondisi ekonomi umumnya pihak mitra usaha yang hanya berharap pada hasil usaha yang ditekuni. Karena itu, melalui pem- 
berian asuransi pendidikan sebagai salah satu produk Mudharabah sangat membantu meringankan beban mitra usaha untuk menangani pembiayaan pendidikan anaknya, karenanya pihak bank memberikan asuransi untuk menanggulangi pembiayaan tersebut dan meringankan beban biaya yang ditang-gung dalam pembiayaan yang besar. Melalui penerapan produk mudharabah konsumtif melalui asuransi pendidikan memberikan pengaruh terhadap peningkatan partum-buhan UMKM yang ada di Kota Palopo.

Sama halnya dengan penerapan pro-duk mudharabah konsumtif berupa asuransi kesehatan, di mana pembiayaan kesehatan untuk berobat, pemeriksaan, operasi, dan berbagai kegiatan pengobatan ditanggung oleh pihak bank dalam pembiayaannya. Karenanya pihak mitra sangat terbantu di dalam pengeluaran pembiayaan kesehatan yang sewaktu-waktu dapat terjadi dan dialami oleh pihak mitra usaha. Karena itu, pihak mitra sangat terbantu dengan adanya produk mudharabah konsumtif yang diberi-kan oleh pihak perbankan dalam menjalani usahanya, dan ini berdampak terhadap pertumbuhan UMKM yang ada di Kota Palopo.

Berdasarkan uraian di atas, diketahui bahwa produk mudharabah konsumtif yang diberikan oleh pihak perbankan sebagai produk yang dapat dimanfaatkan dan digunakan oleh pihak mitra untuk meringan-kan beban pembiayaan dalam usaha dan pemenuhan kebutuhannya. Karena itu pro duk mudharabah konsumtif berupa KPR, KPM, pendidikan dan kesehatan berpenga-ruh positif dan signifikan terhadap pertumbuhan UMKM yang dikembangkan oleh pihak mitra dalam mengembangkan usaha dan memenuhi kebutuhan konsumtifnya.

Teori mendukung yaitu teori perilaku konsumtif dikemukakan oleh Norton (2003:71) bahwa manusia dalam mengem-bangkan perilaku konsumtif mempunyai ketertarikan terhadap barang dan jasa yang dilakukan secara tidak rasional. Pertimbang-an tidak rasional ini menjadikan aktivitas perputaran dana masyarakat perlu diman-faatkan dan digunakan untuk penguatan eko-nomi. Perilaku konsumtif cenderung pada pertimbangan yang tidak rasional untuk memenuhi keinginan. Perilaku inilah yang dimanfaatkan untuk memperoleh keuntung-an melalui proses pemberian, 
peminjaman, atau bantuan insentif. Semakin terpelihara perilaku konsumtif tersebut, maka semakin diperoleh keuntungan dari tindakan yang tidak rasional. Termasuk dalam hal ini adalah konsep pemberian konsumtif kepada nasabah.

Termasuk teori yang mendukung adalah teori kebutuhan hidup (life need theory) bahwa setiap orang berupaya untuk memenuhi kebutuhan hidupnya. Upaya untuk memenuhi kebutuhan hidup dilakukan dengan metode dan cara yang ringan dan tidak terbebani. Termasuk salah satunya yang dilakukan oleh pihak perbankan yang menawarkan produk mudharabah konsumtif kepada nasabah atau mitra usaha untuk meringankan beban pembiayaan dalam memenuhi kebutuhan hidup dalam berusaha dan kebutuhan kelangsungan hidup. Contoh, KPR, KPM, asuransi dan kesehatan.

\section{PENUTUP}

Berdasarkan hasil penelitian, maka kesimpulan penelitian ini adalah sebagai berikut:

1. Secara simultan hasil penelitian ini membuktikan bahwa produk mudha-rabah Bank Muamalat Syariah berupa modal kerja, investasi dan konsumtif secara simultan berpengaruh signifikan positif terhadap pertumbuhan UMKM di Kota Palopo. Dan secara parsial produk tersebut telah diterapkan kepada setiap katkan pertumbuhan UMKM di Kota Palopo.

2. Berdasarkan hasil penelitian ditemukan bahwa modal kerja yang dominan berpengaruh signifikan positif terhadap pertumbuhan UMKM di Kota Palopo. Artinya dengan pemberian modal kepada klien atau nasabah sesuai dengan ketentuan dan prasyarat yang dapat dijaminkan, akan mendukung peningkatan pertumbuhan UMKM sesuai dengan pemberian modal kerja primer, normal, musiman, siklis dan darurat.

\section{DAFTAR PUSTAKA}

Arifin, Zainul, 1999, Memahami Bank Syariah; Lingkup, Peluang, Tantangan dan Prospek, Alfabeta, Bandung. 
Azis, Amin, 1992, Mengembangkan Bank Islam di Indonesia, Bangkit, Jakarta.

Chapra, Umer, 2005. Manajemen Pemasaran Bank Syariah. Penerbit Dian Sarana Ilmu, Bandung.

Darmono, Anwari, 2003. Praktek Perbankan di Indonesia, Balai aksara, Jakarta

Teori dan Praktek, Remaja Rosdakarya, Bandung.

Faried, Widjaja, 1999, Lembaga Perbankan di Indonesia, Ghalia Indonesia, Jakarta.

Hadiwidjaja,H. dan R.A. Rivai Wirasamita. 1991. Analisis Kredit (Dilengkapi Telaah Kasus), Pionir Jaya, bandung.

Haslem, H.R., 1985. Implementasi Kebijakan Perbankan dan Keuangan. Penerbit Prenada, Surabaya.

Kasmir, 2002. 